These are of course minor criticisms, and I would like to conclude by recommending the book very widely to all students of the brain and to all those interested in the history of the remarkable discoveries that have been made in this field: I have myself recommended it to my research associates. It is too often a temptation to the young investigator to narrow his field of interest unduly. A book such as Explorers of the Brain will open to him most attractive vistas in this immensely exciting field.

J. C. ECCles

\section{Clouds of Glory}

Early Human Development. Edited by S. J. Hutt and Corinne Hutt. Pp. viii + 362. (Oxford University: London; Clarendon: Oxford, June 1973. £2.75 boards; $£ 1.50$ paper.

THIs book should be called "Readings in Early Human Development". It reprints twenty-nine papers (some mercifully shortened), grouped in seven sections. Each section has a brief but well documented introduction. Most of the papers are without summaries. There is a perfunctory subject index, but no index of authors.

The first section, on genetical influences on behaviour, begins well. The editors give as the important general questions, "How much of the variance of scores on a particular trait under certain environmental conditions can be attributed to genetic factors? How modifiable is the phenotypic expression of such a trait? How do genetic and environmental influences interact?" Unfortunately, in the introduction to section 5, they drift into the usual confusion between genetical and ontogenetic determination; but this is only a minor lapse.

After the genetical section, three papers deal with hormones and behaviour. The third describes some unexpected findings which suggest that dosing a pregnant woman with progesterone can accelerate the early physical development of her child and can later enhance his intellectual development. The next section, entitled "Early Brain Mechanisms", is inevitably gravelled for lack of matter. It includes a study of rhythms of sleep and waking, and one on the effect of cycles of internal state on responsiveness to external stimulation.

Perception is covered by three papers on vision and one on auditory discrimination. The recent important work on the effects of errors of refraction on the development of vision was perhaps published too late for inclusion.

Two sections, under the headings of "Attachment" and "Early Experience", include papers on maternal deprivation. A classical paper by John Bowlby, published 21 years ago, is rightly in-

cluded; and there are more recent and more critical studies in the same field, notably one by $\mathbf{H}$. R. Schaffer entitled "Maternal Deprivation or Perceptual Deprivation?". Another paper discusses the reversibility of the effects of early lack of mothering. But some important investigations, which attempt to relate the precise nature of the deprivation to subsequent development, are not represented.

Finally there are six papers on stimu. lation in early life and on the development of fear. These illustrate, among other things, the importance of this topic and how much remains to be learnt about it.

This is a useful collection. It includes papers which illustrate some of the many methodological hazards of work in this field. It would have been still more useful if the editors had written more, and so filled some of the gaps. Among special but important items not adequately covered are researches on sucking and - still more notable investigations of intellectual development in the first year. The editors seem to have some doubts about the usefulness of cross-cultural studies, and they are not represented. These include findings, on the influence of social class on development, which ought to influence social policy. But if, as the editors rightly assume, comparisons with other species can suggest testable hypotheses about man, then comparisons of human groups can do so too.

Despite omissions, some of them no doubt inevitable, this volume gives a helpful and instructive picture of a region of study which is now full of life and could hardly be more important.

S. A. BARNETT

\section{The Airport Affair}

A Sadly Mismanaged Affair: A Political History of the Third London Airport. By David McKie. Pp. 256. (Croom Helm: London, October 1973.) £3.75.

David McKIE, of The Guardian, tells a lively tale of the political problems of deciding where London's third airport should go. In 1944 Lord Swinton, Minister of Civil Aviation, had been able to say of Heathrow that it was the "only possible site" for London's airport. No one is so sure about anything in 1973. The book takes us briskly through Croydon, Heathrow, Gatwick, Stansted, Cublington, Thurleigh, Nuthampstead and Foulness, and it is clear, after the inquiries and committees, that it is possible to prove anything once the terms of reference are designed properly. Even so, an airport seems to be one monument to which politicians don't crave to have their names attached.

Roskill is viewed with some awe and, it must be said, doesn't come over very clearly. One senses that $\mathrm{Mr}$ McKie has not really tried to understand the technical side of the issues at all, as is his privilege in what he calls a political history. Nevertheless, this does make the book somewhat unsatisfactory. There are no figures on the predictions and realities of usage of airports, on the impact of wide-bodied jets on airport planning, on the levels of noise at varying radii from airports, on the improved noise performance of modern engines and on many other technical issues. The reason that the planning process has been so tortuous is not simply that there have been local objections; the technical ground has been shifting continuously under the politicians' feet. The book is incomplete, however readable, without the driving forces being in clearer focus,

D. Davies

\section{Plasmids}

Bacterial Plasmids: Conjugation, Colicinogeny and Transmissible DrugResistance. By G. G. Meynell. Pp. xiii + 164. (MIT: Cambridge, May 1973.) $\$ 14.99$.

DURING the past decade there has been a considerable expansion in the study of bacterial plasmids. From the early days, when the plasmid $F$ served as a mere tool for unravelling the intricacies of Escherichia coli genetics, their importance has increased concomitant with the realisation that quite unrelated plasmids are of relatively frequent occurrence in many bacterial genera, and that in many cases they have the ability to cross interspecies and intergeneric boundaries. Combined with their ability to carry genes determining resistance of the host to antibiotics, these properties give them great medical importance, while their ability to transfer host chromosomal genes suggests that they may play a significant role in the evolution of bacterial species.

There will therefore be wide interest in this book, which sets out to review the important biological characteristics of bacterial plasmids. The three central chapters (chapters 5, 6 and 7) deal with their transmission from cell to cell by conjugation, their replication within the cell as autonomous DNA molecules, and the physical properties of these molecules. These chapters provide a brief but adequate introduction to plasmid biology, although, inevitably for a book written two years ago about a rapidly-expanding field, much important recent information is absent. In particular, the chapter on conjugation is noticeably out of date, and topics such as the discovery of a large number of plasmid incompatibility groups, and the use of electron microscope heteroduplex tech- 